\title{
A metformin hatása a vérzsírértékekre, illetve a szív és érrendszeri kockázatra sztatinkezelésben nem részesülő 2-es típusú cukorbetegekben
}

\author{
Kender Zoltán dr., 2,3 . Groener Jan Benedikt dr. ${ }^{1,2}$ \\ Reismann Péter dr. ${ }^{4}$ - Kopf Stefan dr. ${ }^{1,2}$ \\ ${ }^{1}$ Department of Internal Medicine I and Clinical Chemistry, University of Heidelberg, Heidelberg, Germany \\ ${ }^{2}$ German Center for Diabetes Research (DZD), Munich-Neuherberg, Germany \\ ${ }^{3}$ Semmelweis Egyetem, Általános Orvostudományi Kar, Rácz Károly Doktori Iskola, Budapest \\ ${ }^{4}$ Semmelweis Egyetem, Általános Orvostudományi Kar, II. Belgyógyászati Klinika, Budapest
}

\begin{abstract}
Bevezetés: Számos vizsgálat és metaanalízis alátámasztotta a metforminkezelés pozitív hatását a lipidparaméterekre, ugyanakkor a metforminkezelés cardiovascularis rizikóra gyakorolt hatása továbbra sem tisztázott.

Célkitüzés: Vizsgálatunk célja a metforminkezelés hatásának vizsgálata a lipidparaméterekre és a cardiovascularis rizikóra 2-es típusú cukorbetegekben.

Módszer: Egy monocentrikus, keresztmetszeti vizsgálat keretében 102, antilipaemiás kezelésben nem részesülő, 2-es típusú cukorbeteg adatait dolgoztuk fel a szérum-lipidparaméterek és a cardiovascularis rizikó tekintetében (a United Kingdom Prospective Diabetes Study rizikókalkulátor alapján). A betegeket két csoportra osztottuk, metformint szedőkre $(\mathrm{n}=52)$ és metforminterápiában nem részesülőkre $(\mathrm{n}=50)$.

Eredmények: A metforminkezelésben részesülő betegek esetében a glikémiás paraméterektől függetlenül szignifikánsan alacsonyabb össz- és LDL-koleszterin-szinteket találtunk $(\mathrm{p}<0,01$, illetve $\mathrm{p}<0,05)$. A szisztolés vérnyomás, a HDL-koleszterin- és a trigliceridszintek, valamint a több paramétert vizsgáló, kockázatbecslő számítás alapján a szívér rendszeri kockázat tekintetében nem találtunk érdemi eltérést a két betegcsoport között.

Következtetés: Vizsgálatunk megerősíti a metforminkezelés koleszterin- és LDL-koleszterin-szintekre gyakorolt pozitív hatását a cardiovascularis rizikó csökkentése nélkül.
\end{abstract}

Orv Hetil. 2019; 160(34): 1346-1352.

Kulcsszavak: metformin, 2-es típusú cukorbetegség, koleszterin, LDL-koleszterin, cardiovascularis rizikó

\section{The effect of metformin on lipid parameters and on cardiovascular risk in patients with type 2 diabetes without statin therapy}

Introduction: Some meta-analyses suggested a positive effect of metformin therapy on lipid parameters, but the potential beneficial effect of metformin on cardiovascular risk in type 2 diabetes is not entirely clear.

Aim: We investigated the effect of metformin therapy on lipid parameters and cardiovascular risk in patients with type 2 diabetes.

Method: In a cross-sectional, monocentric study, 102 patients with type 2 diabetes without lipid-lowering medication were analysed for lipid profile and cardiovascular risk (United Kingdom Prospective Diabetes Study Risk Calculator) depending on metformin therapy. The patients were divided into two subgroups regarding with $(\mathrm{n}=52)$ or without metformin therapy $(\mathrm{n}=50)$.

Results: Patients with metformin therapy had significantly lower total cholesterol and LDL cholesterol levels than patients without metformin $(\mathrm{p}<0.01$ and $\mathrm{p}<0.05)$. This effect was independent from glucose control. No intrinsic effect of metformin could be found on systolic blood pressure, HDL cholesterol, triglycerides, and long-term cardiovascular risk using a multivariable risk assessment score.

Conclusion: Metformin therapy has beneficial effects on cholesterol levels without improving cardiovascular risk in patients with type 2 diabetes. 
Keywords: metformin, type 2 diabetes, cholesterol, LDL cholesterol, cardiovascular risk

Kender Z, Groener JB, Reismann P, Kopf S. [The effect of metformin on lipid parameters and on cardiovascular risk in patients with type 2 diabetes without statin therapy]. Orv Hetil. 2019; 160(34): 1346-1352.

(Beérkezett: 2019. május 25.; elfogadva: 2019. június 15.)

\begin{abstract}
Rövidítések
ACCORD = Action to Control Cardiovascular Risk in Diabetes; ACR = (albumin-kreatinin ratio) albumin-kreatinin arány; ADVANCE $=$ Action in Diabetes and Vascular Disease: Preterax and Diamicron $-\mathrm{MR}$ controlled evaluation; AGE = (advanced glycation end-products) késői glikációs végtermékek; AMP $=$ adenozil-monofoszfát $;$ AMPK $=\left(5^{\prime}\right.$-AMP-activated protein kinase) 5'-AMP-aktivált proteinkináz; ANOVA = (analysis of variance) varianciaanalízis; $\mathrm{AP}=$ alkalikus foszfatáz; $\mathrm{ATP}=$ adenozil-trifoszfát; $\mathrm{BMI}=$ (body mass index) testtömegindex; CKD-EPI = Chronic Kidney Disease-Epidemiology Collaboration; DDP4 = dipeptidil-peptidáz-4; EKG = elektrokardiográfia; $\mathrm{FADSl}=($ fatty acid desaturase 1$)$ zsírsav-deszaturáz- 1 ; GFR $=$ glomerulusfiltrációs ráta; GGT $=$ gamma-glutamiltranszferáz; GLPl = (glucagone-like peptide 1) glükagonszerü peptid-1; GOT = glutamát-oxálacetát-transzamináz; GPT = glutamát-piruvát-transzamináz; $\mathrm{HbA}_{\mathrm{lc}}=$ hemoglobin $\mathrm{A}_{1 \mathrm{c}}$; $\mathrm{HDL}=$ (high-densitiy lipoprotein) magas denzitású lipoprotein; HMG-CoA = (3-hydroxy-3-methylglutaryl-coenzyme A reductase) 3-hidroxi-3-metilglutaril-koenzim-A-reduktáz; IMPROVE-IT = IMProved Reduction of Outcomes: Vytorin Efficacy International Trial; LDL $=$ (low-density lipoprotein $)$ alacsony denzitású lipoprotein; RAAS = (renin-angiotensin-aldosterone system) renin-angiotenzin-aldoszteron rendszer; SEM $=$ (standard error of the mean $)$ a középérték közepes hibája; SGLT2 $=($ sodium glucose co-transporter 2$)$ nátrium-glükóz-kotranszporter-2; SREBPl = (sterol regulatory elementbinding protein 1) szterolelemet kötő szabályozófehérje-1; $\mathrm{TG}=$ triglicerid; $\mathrm{TSH}=$ tireotropstimuláló hormon; UKPDS = United Kingdom Prospective Diabetes Study; VADT $=$ Veterans Affairs Diabetes Trial
\end{abstract}

A 2-es típusú cukorbetegség okozta nagyérrendszeri szövődmények jelentős szerepet játszanak ezen betegcsoport szív-ér rendszeri morbiditásában és mortalitásában [1]. A 2-es típusú diabetesre alapvetően jellemző komplex szénhidrátanyagcsere-zavar (inzulinrezisztencia és az ehhez társuló károsodott béta-sejt-funkció kiváltotta relatív inzulinhiány) okozta emelkedett vércukorszint mellett gyakran jelen van a zsíranyagcsere szerzett vagy örökletes zavara, amely szintén hozzájárul ezen betegcsoport fokozott cardiovascularis rizikójához $[2,3]$. A nagy esetszámot magukban foglaló, randomizált klinikai vizsgálatok (UKPDS, ACCORD, ADVANCE, VADT) nem tudták egyértelmúen igazolni az intenzív vércukorcsökkentő kezelés kedvező hatását a macrovascularis szövődményekre, illetve az ezek által okozott mortalitásra, sőt az ACCORD-vizsgálat során az agresszív antiglikémiás kezelés mortalitást fokozó hatását észlelték [4-8]. A UKPDS-vizsgálat hosszú távú, passzív utánkövetése során azonban a szívinfarktus kockázatának mérsékelt csökkenését figyelték meg a vizsgálat korábbi, aktív szakaszában intenzív vércukorcsökkentő kezelésben részesülő betegek körében [9].

Az emelkedett koleszterinszint cardiovascularis morbiditást és mortalitást fokozó hatását számos tanulmány igazolta [10-12]. Ám a koleszterinszint-csökkentő HMG-CoA-gátló (sztatin-) kezeléssel folytatott vizsgálatok eredményét összefoglaló metaanalízis nem támasztotta alá a primer prevencióként alkalmazott sztatinkezelés pozitív hatását a cardiovascularis események előfordulására magas rizikójú betegek körében [13]. Az IMPROVE-IT-vizsgálat alapján a kombinált koleszterincsökkentő kezelés (sztatin + ezetimib) a halált okozó végpontok csökkentése nélkül mérsékelte a cardiovascularis események előfordulási gyakoriságát [14]. Igazán jelentős eredményt a szív- és érrendszeri megbetegedés, illetve halálozás tekintetében kizárólag az intenzív multifaktoriális kezelés (vércukorkontroll, acetilszalicilsav, RAAS-gátló kezelés, antilipaemiás terápia) hatására sikerült elérni a Steno-2-vizsgálat során 2-es típusú cukorbetegségben [15].

Az utóbbi években számos, a metforminterápiának a zsíranyagcserére és a cardiovascularis rizikóra gyakorolt hatását vizsgáló metaanalízis született egymásnak ellentmondó eredményekkel [16-18]. Sok esetben a párhuzamosan folytatott antilipaemiás kezelés nehezítette a metformin koleszterincsökkentő hatásának értékelését. Eddig egy tanulmány vizsgálta célzottan a metforminkezelés metabolikus profilra gyakorolt hatását, 2 -es típusú cukorbetegségben amely vizsgálat a metforminkezelés LDL-koleszterin-szintet csökkentő hatását támasztotta alá [17]. Továbbá egy közelmúltban megjelent metaanalízis a metforminkezelés lipidanyagcserére kifejtett pozitív hatására hívta fel a figyelmet a testtömeg mérsékelt, ugyanakkor szignifikáns csökkentése mellett 60 év feletti, 2-es típusú cukorbetegek körében [19].

A jelen keresztmetszeti vizsgálatunk során az általunk vizsgált 2-es típusú cukorbetegek körében kívántuk felmérni a metforminkezelés hatását a lipidanyagcserére és a cardiovascularis rizikóra.

\section{Módszer}

A Ruprecht Karl Egyetem I. Sz. Belgyógyászati Klinikájának (Heidelberg, Németország) diabetesambulanciáján (Clinical Study Center for Diabetes Research) egy klinikai vizsgálatban (Heidelberg Study on Diabetes and 
Complication) részt vevő 348, 2-es típusú cukorbeteg közül 102 beteg adatait dolgoztuk fel. Minden, a vizsgálatban részt vevő beteg írásos beleegyezését adta a helsinki deklaráció irányelveinek megfelelően. A klinikai vizsgálat a Heidelbergi Egyetem Etikai Bizottsága által jóváhagyásra (S-383/2016) került, ezenfelül a ClinicalTrials.gov portálon az NCT03022721. szám alatt regisztrált.

Beválasztási kritériumok:

- 2-es típusú cukorbetegség, amelyet >12 hónapja diagnosztizáltak;

- életkor>8 év.

Kizárási kritériumok:

- koleszterincsökkentő és egyéb antilipaemiás kezelés;

- ischaemiás szívbetegség, illetve stroke az anamnézisben;

- pajzsmirigyfunkció-zavar;

- hyperlipidaemiával járó egyéb kórképek;

- szteroidkezelés.

A 2-es típusú cukorbetegség diagnózisa a Német Diabetes Társaság (German Diabetes Association) irányelveinek megfelelően történt, amelyek összhangban állnak az Európai Diabetes Társaság (European Association for the Study of Diabetes) irányelveivel [20]. A laboratóriumi vizsgálatok éhgyomri vérvételt követően azonnali transzportot követően a Heidelbergi Egyetem Központi Laboratóriumában (Department of Medical Chemistry, University of Heidelberg) történtek, standardizált körülmények között. A glomerulusfiltrációs ráta meghatározása a CKD-EPI-képlet alapján történt [21]. Minden beteg esetében rutin 12 elvezetéses EKG-vizsgálat készült.

A cardiovascularis rizikó becslésére a UKPDS-vizsgálat adatai ( 53000 betegév) alapján kifejlesztett diabetesspecifikus rizikókalkulátort alkalmaztuk (UKPDS Risk Engine, www.dtu.ox.ac.uk/riskengine). A rizikókalkulátor az igazolt ischaemiás szívbetegség nélküli, 2-es típusú cukorbetegek esetében végez az elkövetkező 10 évre vonatkoztatott rizikóbecslést a következő eseményekre: coronariabetegség, halált okozó coronariabetegség, stroke, halált okozó stroke. A rizikókalkulátor a következő paraméterek figyelembevételével végzi a rizikóbecslést: életkor, nem, a cukorbetegség időtartama, $\mathrm{HbA}_{\mathrm{lc}}$, szisztolés vérnyomás, pitvarfibrilláció megléte, etnikai hovatartozás, teljes szérumkoleszterin, HDL-koleszterin, dohányzás [22].

\section{Statisztikai analizis:}

Az egyes adatok elemzése során minden esetben figyelembe vettük az adatok normális vagy nem normális eloszlását (Kolmogorov-Szmirnov-teszt), ennek megfelelően a folytonos változók esetében egyszempontos varianciaanalízist (one-way ANOVA) vagy Mann-Whitney-féle U-tesztet alkalmaztunk. A kategoriális változók vizsgálatát khi-négyzet-próbával végeztük. Lineáris regresszióanalízist végeztünk, amelynek során függő változóként az LDL-koleszterin-szintet vettük, a következő változók mint független változók figyelembevételével: életkor, nem, diabetes-időtartam, BMI, GFR-EPI, $\mathrm{HbA}_{\mathrm{lc}}$, metforminkezelés, RAAS-gátló kezelés, acetilszalicilsav-kezelés, Ca-antagonista-kezelés, TSH. A statisztikai elemzések során a szignifikanciaszintnek a $\mathrm{p}<0,05$ értéket vettük. A statisztikai elemzéseket az SPSS statisztikai program segítségével végeztük (SPSS Version 23.0, IBM Corporation, Armonk, NY, Amerikai Egyesült Államok).

\section{Eredmények}

A beválasztási és kizárási kritériumoknak megfelelően 102 beteg adatainak elemzését végeztük el. A betegeket két csoportra osztottuk az antidiabetikus kezelés alapján: metforminkezelésben nem részesülő betegek $(n=50)$ és metforminkezelésben részesülő betegek $(n=52)$. A metformin napi dózisa 1000-3000 mg között volt (az alkalmazott dózis medián értéke $2000 \pm 86,91$ [SEM] mg). A két betegcsoport között nem találtunk érdemi eltérést az életkor, a nem, a betegségtartam, a BMI, a gyógyszeres kezelés, a szisztolés vérnyomás és az aktuális szénhidrát-anyagcsere állapotának tekintetében. A vizsgált betegek adatait és részletes laboratóriumi paramétereit az 1. táblázat mutatja be.

A két vizsgált csoport összehasonlítása során szignifikáns eltérést tapasztaltunk a szérum-teljeskoleszterin$(225,40 \pm 7,37$ vs. $196,98 \pm 4,85 \mathrm{mg} / \mathrm{dl} ; \mathrm{p}<0,01)$ és a szérum-LDL-koleszterin-koncentráció $(134,17 \pm 6,52$ vs. $114,96 \pm 4,45 \mathrm{mg} / \mathrm{dl} ; \mathrm{p}<0,05)$ esetében. Mindkét paraméter alacsonyabb értéket mutatott a metforminkezelésben részesülők körében. Ugyanakkor a szérumtriglicerid- és a HDL-koleszterin-szintek között nem találtunk statisztikailag szignifikáns különbséget (1. táblázat).

A UKPDS-rizikókalkulátorral végzett 10 éves rizikóbecslés eredményeiben nem észleltünk eltérést a két betegcsoport között, sem a coronariabetegség $(23,5 \%$ vs. $24,6 \%)$, sem a stroke (15,9\% vs. $15,9 \%)$ rizikójának tekintetében (1. táblázat).

A lineáris regresszióanalízis során sem találtunk a metforminkezelésen kívül olyan tényezőt, amely e két betegcsoport esetében szignifikáns hatással bírna a szérumLDL-koleszterin-szintre. A regresszióanalízis eredményét a 2. táblázat mutatja be.

\section{Megbeszélés}

Eredményeink alátámasztják a metforminkezelés egyéb tényezőktől (életkor, BMI, betegségtartam és egyéb gyógyszeres kezelés) független összkoleszterin- és LDLkoleszterin-szintet csökkentő hatását, antilipaemiás kezelésben nem részesülő 2-es típusú cukorbetegek körében. Ezen eredmény összhangban áll a korábbi metaanalízisek eredményeivel, amelyek a metforminkezelés 
1. táblázat

\section{| A vizsgált betegcsoportok jellemzői}

\begin{tabular}{|c|c|c|}
\hline & $\begin{array}{l}\text { Metforminkezelés- } \\
\text { ben nem részesülő } \\
\text { betegek } \\
(\mathrm{n}=50)\end{array}$ & $\begin{array}{c}\text { Metforminkezelés- } \\
\text { ben részesülő } \\
\text { betegek } \\
(\mathrm{n}=52)\end{array}$ \\
\hline Életkor (év) & $63,04 \pm 1,55$ & $62,88 \pm 1,50$ \\
\hline Nem (nő/férfi) & $25 / 25$ & $21 / 31$ \\
\hline Betegségtartam (év) & $10,72 \pm 1,65$ & $10,04 \pm 1,19$ \\
\hline Szulfanilureakezelés & $2(4)$ & $2(3,8)$ \\
\hline DPP4-gátló kezelés & $6(12)$ & $13(25)$ \\
\hline GLPl-analóg kezelés & $2(4)$ & $0(0)$ \\
\hline SGLT2-gátló kezelés & $5(10)$ & $6(11,5)$ \\
\hline Inzulinterápia & $12(24)$ & $11(21,6)$ \\
\hline Acetilszalicilsav-kezelés & $6(12)$ & $10(19,2)$ \\
\hline RAAS-gátló kezelés & $20(40)$ & $29(55,8)$ \\
\hline Béta-blokkoló-kezelés & $12(24)$ & $14(26,9)$ \\
\hline Ca-antagonista-kezelés & $6(12)$ & $12(23,1)$ \\
\hline Hypertoniabetegség & $30(60)$ & $36(69,2)$ \\
\hline Dohányzás & $3(6)$ & $7(13,5)$ \\
\hline BMI $\left(\mathrm{kg} / \mathrm{m}^{2}\right)$ & $30,73 \pm 0,95$ & $32,40 \pm 0,86$ \\
\hline $\mathrm{HbA}_{\mathrm{lc}}(\%)$ & $7,11 \pm 0,21$ & $7,14 \pm 0,14$ \\
\hline $\mathrm{HBA}_{\mathrm{lc}}(\mathrm{mmol})$ & $54,55 \pm 2,24$ & $53,29 \pm 1,69$ \\
\hline $\operatorname{ACR}(\mathrm{mg} / \mathrm{g})$ & $161,37 \pm 109,67$ & $172,9 \pm 98,60$ \\
\hline GFR-EPI $\left(\mathrm{ml} / \mathrm{min}^{*} 1,73 \mathrm{~m}^{2}\right)$ & $84,94 \pm 2,59$ & $90,13 \pm 2,46$ \\
\hline Koleszterin $(\mathrm{mg} / \mathrm{dl})$ & $225,40 \pm 7,37$ & $196,98 \pm 4,85$ * * \\
\hline Triglicerid (mg/dl) & $206,42 \pm 37,2$ & $180,35 \pm 15,07$ \\
\hline HDL-koleszterin $(\mathrm{mg} / \mathrm{dl})$ & $50,8 \pm 2,93$ & $46,85 \pm 1,43$ \\
\hline LDL-koleszterin (mg/dl) & $134,17 \pm 6,52$ & $114,96 \pm 4,45^{*}$ \\
\hline $\operatorname{GOT}(\mathrm{U} / \mathrm{l})$ & $29,56 \pm 3,44$ & $28,19 \pm 2,10$ \\
\hline GPT $(U / 1)$ & $31,6 \pm 3,34$ & $33,25 \pm 3,28$ \\
\hline $\mathrm{AP}(\mathrm{U} / \mathrm{l})$ & $75,24 \pm 3,68$ & $73,75 \pm 2,71$ \\
\hline GGT (U/1) & $52,28 \pm 15,6$ & $44,92 \pm 7,11$ \\
\hline $\mathrm{TSH}(\mathrm{mU} / \mathrm{l})$ & $1,66 \pm 0,12$ & $1,67 \pm 0,17$ \\
\hline $\mathrm{CRP}(\mathrm{mg} / \mathrm{l})$ & $3,46 \pm 0,61$ & $3,35 \pm 0,44$ \\
\hline $\begin{array}{l}\text { Szisztolés vérnyomás } \\
(\mathrm{Hgmm})\end{array}$ & $138,06 \pm 3,13$ & $134,92 \pm 2,04$ \\
\hline \multicolumn{3}{|l|}{ UKPDS-rizikó score (10 év) } \\
\hline $\begin{array}{l}\text { coronariabetegség } \\
\text { halálhoz vezetô coronariabe- }\end{array}$ & $23,5 \%$ & $24,6 \%$ \\
\hline tegség & $18,0 \%$ & $18,7 \%$ \\
\hline stroke & $15,9 \%$ & $15,9 \%$ \\
\hline halálhoz vezető stroke & $2,8 \%$ & $3,0 \%$ \\
\hline
\end{tabular}

Adatok: átlag \pm SEM (a középérték közepes hibája) vagy $\mathrm{n}$ (\%). ${ }^{*} \mathrm{p}<0,05 ;{ }^{*} \mathrm{p}<0,01$

$\mathrm{ACR}=$ albumin-kreatinin arány $\mathrm{AP}=$ alkalikus foszfatáz; $\mathrm{BMI}=$ test tömegindex; CRP = C-reaktív protein; DPP4 = dipeptidil-peptidáz-4; GFR = glomerulusfiltrációs ráta; GGT = gamma-glutamin-transzferáz; GLPl = glükagonszerű peptid-1; GOT = glutamát-oxálacetát-transzamináz; GPT = glutamát-piruvát-transzamináz; $\mathrm{HbA}_{\mathrm{lc}}=$ hemoglobin $\mathrm{A}_{\mathrm{lc}} ; \mathrm{HDL}=$ magas denzitású lipoprotein; $\mathrm{LDL}=$ alacsony denzitású lipoprotein; RAAS = renin-angiotenzin-aldoszteron rendszer; SGLT2 = nátrium-glükóz-kotranszporter- $2 ; \mathrm{TG}=$ triglicerid $; \mathrm{TSH}=$ tireotropstimuláló hormon
2. táblázat | Lineáris regresszióanalízis - az egyes paraméterek LDL-koleszterin-szintre gyakorolt hatásának vizsgálata

\begin{tabular}{lccc}
\hline Vizsgált paraméter & B-koefficiens & T-érték & P-érték \\
\hline Életkor & $-0,16$ & $-0,149$ & 0,88 \\
Nem & 0,086 & 0,790 & 0,43 \\
Betegségtartam & 0,203 & 1,911 & 0,06 \\
BMI & 0,055 & 0,504 & 0,62 \\
GFR-EPI & 0,057 & 0,515 & 0,61 \\
HbA 1 c & 0,085 & 0,781 & 0,44 \\
Metforminkezelés & $-0,236$ & $-2,188$ & $0,032 *$ \\
RAAS-gátló kezelés & 0,04 & 0,37 & 0,71 \\
Acetilszalicilsav-kezelés & 0,182 & 1,683 & 0,09 \\
Béta-blokkoló-kezelés & 0,171 & 1,596 & 0,11 \\
Ca-antagonista-kezelés & 0,043 & 0,39 & 0,70 \\
TSH & 0,101 & 0,93 & 0,355 \\
\hline
\end{tabular}

${ }^{*} \mathrm{p}<0,05$

$\mathrm{BMI}=$ testtömegindex $; \mathrm{HbA}_{\mathrm{lc}}=$ hemoglobin $\mathrm{A}_{\mathrm{lc}} ; \mathrm{GFR}=$ glomerulus filtrációs ráta; $\mathrm{LDL}=$ alacsony denzitású lipoprotein; RAAS = renin angiotenzin-aldoszteron rendszer; TSH = tireotropstimuláló hormon

teljeskoleszterin- és LDL-koleszterin-szintekre gyakorolt pozitív hatását írták le, a szérumtriglicerid, a HDLkoleszterin és más rizikófaktorok csökkentése nélkül [16, $18,23]$.

A metformin mint antidiabetikum évtizedek óta a 2-es típusú cukorbetegség egyik bázisgyógyszere, az aktuális ajánlások alapján jelenleg az elsőként választandó antidiabetikum $[24,25]$. Ennek ellenére hatásmechanizmusa számos tekintetben tisztázatlan. A jól ismert hatásmechanizmusok (a szénhidrátok felszívódásának gátlása, az inzulinrezisztencia csökkentése, a hepaticus glükózprodukció gátlása, GLPl-aktiváló hatás) $[26,27]$ mellett feltételezhetô, hogy a zsíranyagcserére gyakorolt hatásának hátterében szervspecifikus pleiotrop hatásmechanizmusok állnak [28]. Egyrészt szerepe lehet a táplálkozási szokásokra gyakorolt központi idegrendszeri hatásának, amely a hypothalamicus AMPK-gátló, illetve GLPl-aktiváló hatáson keresztül csökkent éhségérzethez és következményes csökkent táplálékfelvételhez vezet $[29,30]$. Ugyanakkor a májsejtekben az AMP/ATP arány növelésének következtében fokozott AMPK-aktivitáshoz vezet, amely az SREBP Ic transzkripciós faktor gátlásán keresztül a zsírsav-deszaturáz-l és -2 (FADSl és -2) csökkent aktivitását, a többszörösen telítetlen zsírsavak (például arachidonsav) és az LDL-koleszterin csökkent szintézisét idézi elő $[17,31,32]$. Az arachidonsav és származékai egy közelmúltban megjelent tanulmány szerint jelentős szerepet játszanak a koleszterin-anyagcserében [33]. Egyes vizsgálatok a metformin epigenetikus hatását is alátámasztották, amelynek ugyancsak szerepe lehet az anyagcserére gyakorolt komplex hatásmechanizmusban $[34,35]$. Számos részlet azonban továbbra is tisztázatlan 
a metformin zsíranyagcserére gyakorolt molekuláris hatásmechanizmusában.

A korábbi randomizált vizsgálatokkal és nagy metaanalízisekkel összhangban a jelen vizsgálatunk sem tudta alátámasztani a metforminkezelés feltételezett, cardiovascularis rizikót csökkentő hatását. Fontos azonban kiemelni, hogy vizsgálatunk viszonylag kis esetszámú, illetve keresztmetszeti jellegü, ennek megfelelően a cardiovascularis rizikó csupán becsléssel volt vizsgálható.

A metforminnek a szív- és érrendszeri betegségek kockázatára gyakorolt hatásával kapcsolatban ellentmondásos irodalmi adatok állnak rendelkezésre. A metforminterápiának a szív- és érrendszeri kemény végpontokra gyakorolt hatását igazoló randomizált, placebokontrollált tanulmány nem áll rendelkezésre. Egyes tanulmányok azonban a metformin pozitív hatását igazolták a szív- és érrendszeri megbetegedésekre [36, 37], illetve ezek kockázati paramétereire (például szisztolés vérnyomás, arteria carotis intima-media vastagság) [16, 23, 38-40]. Ugyanakkor a nagy esetszámot magukban foglaló metaanalízisek eredményei továbbra is ellentmondásosak. Kérdéses, hogy a feltételezett kardioprotektív hatás hátterében elsősorban az antidiabetikus hatás vagy egyéb pleiotrop hatásmechanizmusok állnak.

Számos tanulmány született a metformin szív-ér rendszeri „surrogate markerekre” gyakorolt hatásával kapcsolatban, mint például csökkent fibrinogénaktivitás, fokozott fibrinolízis, illetve a thrombocytaaggregatióra kifejtett gátló hatás [41, 42]. Egy korábbi tanulmány kimutatta a metformin endothelfüggő vasodilatatiót okozó hatását [43]. Egyes vizsgálatok igazolták a metformin antiinflammatoricus hatását (csökkent C-reaktívprotein- és tumornekrózisfaktor-aktivitás) is [27]. A hyperglykaemia a reaktív metabolitok fokozott termelödése révén hozzájárul az ún. késői glikációs végtermékek (advanced glycation end-products - AGE) felhalmozódásához. A késői glikációs végtermékek - elsősorban az oxidatív stressz fokozódása révén - nagyban hozzájárulnak az érelmeszesedéshez és ezáltal a macrovascularis szövődmények kialakulásához [44]. Ezen túlmenően az AGE termékek kiemelkedő jelentőséggel bírnak a microvascularis szövődmények patomechanizmusában [45, 46], amelyek közül a diabeteses nephropathiának szintén szerepet tulajdonítanak a szív- és érrendszeri betegségek kialakulásában [47]. A metforminkezelés igazoltan csökkenti mind a reaktív metabolitok, mind a következményes AGE termékek képződését [48-50].

Mindezen hatások ellenére azonban továbbra is kérdéses a metforminterápia macrovascularis szövődményekre gyakorolt megelőző hatása. A metformin hatásainak részletesebb megismerése és megértése elsősorban az egyes szervspecifikus pleiotrop hatások sejtszintű vizsgálatával és az egyes epigenetikai hatások részletesebb feltérképezésével érhető el.

\section{Következtetések}

Vizsgálatunk alátámasztja a metforminkezelés szérumössz- és -LDL-koleszterin-szintet csökkentő hatását 2-es típusú cukorbetegségben, ugyanakkor az általunk vizsgált betegcsoportban a becsült cardiovascularis rizikót nem befolyásolja. Eredményeink összhangban állnak a metforminkezelés szív-ér rendszeri kockázatra gyakorolt hatását vizsgáló metaanalízisekkel. A macrovascularis rizikóra gyakorolt valós hatás vizsgálatára nagy elemszámú, randomizált, prospektív és placebokontrollált vizsgálat lenne alkalmas antilipaemiás és egyéb cardiovascularis rizikót igazoltan befolyásoló kezelésben nem részesülő 2-es típusú cukorbetegek körében.

Anyagi támogatás: A cikk megírása anyagi támogatásban nem részesült.

Szerzői munkamegosztás: K. Z.: A vizsgálat tervezése, adatgyüjtés, adatelemzés, a közlemény megírása. G. J. B.: Adatgyưjjtés, adatelemzés. R. P.: Szakmai támogatás, részvétel a közlemény megírásában. K. S.: A vizsgálat tervezése, vezetése, a statisztikai analízisben való részvétel. A szerzők a cikk végleges változatát elolvasták és jóváhagyták.

Érdekeltségek: A szerzőknek a közlemény megírásával kapcsolatban nincsenek érdekeltségeik.

\section{Irodalom}

[1] Almdal T, Scharling H, Jensen JS, et al. The independent effect of type 2 diabetes mellitus on ischemic heart disease, stroke, and death: a population-based study of 13,000 men and women with 20 years of follow-up. Arch Intern Med. 2004; 164: 1422-1426.

[2] Kahn SE, Cooper ME, Del Prato S. Pathophysiology and treatment of type 2 diabetes: perspectives on the past, present, and future. Lancet 2014; 383: 1068-1083.

[3] Stratton IM, Adler AI, Neil HA, et al. Association of glycaemia with macrovascular and microvascular complications of type 2 diabetes (UKPDS 35): prospective observational study. BMJ 2000; 321: 405-412.

[4] Action to Control Cardiovascular Risk in Diabetes Study Group, Gerstein HC, Miller ME, Byington RP, et al. Effects of intensive glucose lowering in type 2 diabetes. $\mathrm{N}$ Engl J Med. 2008; 358: 2545-2559.

[5] ADVANCE Collaborative Group, Patel A, MacMahon S, Chalmers J, et al. Intensive blood glucose control and vascular outcomes in patients with type 2 diabetes. N Engl J Med. 2008; 358: $2560-2572$.

[6] UK Prospective Diabetes Study (UKPDS) Group. Intensive blood-glucose control with sulphonylureas or insulin compared with conventional treatment and risk of complications in patients with type 2 diabetes (UKPDS 33). Lancet 1998; 352: 837-853. Erratum: Lancet 1999; 354: 602.

[7] UK Prospective Diabetes Study (UKPDS) Group. Effect of intensive blood-glucose control with metformin on complications in overweight patients with type 2 diabetes (UKPDS 34). Lancet 1998; 352: 854-865. Erratum: Lancet 1998; 352: 1558. 
[8] Duckworth W, Abraira C, Moritz T, et al. Glucose control and vascular complications in veterans with type 2 diabetes. $\mathrm{N}$ Engl J Med. 2009; 360: 129-139.

[9] Holman RR, Paul SK, Bethel MA, et al. 10-year follow-up of intensive glucose control in type 2 diabetes. $\mathrm{N}$ Engl J Med. 2008; 359: 1577-1589.

[10] Emerging Risk Factors Collaboration, Di Angelantonio E, Gao $\mathrm{P}$, Pennells L, et al. Lipid-related markers and cardiovascular disease prediction. JAMA 2012; 307: 2499-2506.

[11] Lakka HM, Laksonen DE, Lakka TA, et al. The metabolic syndrome and total and cardiovascular disease mortality in middleaged men. JAMA 2002; 288: 2709-2716.

[12] Wang J, Ruotsalainen S, Moilanen L, et al. The metabolic syndrome predicts cardiovascular mortality: a 13-year follow-up study in elderly non-diabetic Finns. Eur Heart J. 2007; 28: 857864.

[13] Ray KK, Seshasai SR, Erqou S, et al. Statins and all-cause mortality in high-risk primary prevention: a meta-analysis of 11 randomized controlled trials involving 65,229 participants. Arch Intern Med. 2010; 170: 1024-1031.

[14] Cannon CP, Blazing MA, Giugliano RP, et al. Ezetimibe added to statin therapy after acute coronary syndromes. $\mathrm{N}$ Engl J Med. 2015; 372: 2387-2397.

[15] Gaede P, Lund-Andersen H, Parving HH, et al. Effect of a multifactorial intervention on mortality in type 2 diabetes. $\mathrm{N} \mathrm{Engl} \mathrm{J}$ Med. 2008; 358: 580-591.

[16] Wulffelé MG, Kooy A, de Zeeuw D, et al. The effect of metformin on blood pressure, plasma cholesterol and triglycerides in type 2 diabetes mellitus: a systematic review. J Intern Med. 2004; 256: 1-14.

[17] Xu T, Brandmaier S, Messias AC, et al. Effects of metformin on metabolite profiles and LDL cholesterol in patients with type 2 diabetes. Diabetes Care 2015; 38: 1858-1867.

[18] Griffin SJ, Leaver JK, Irving GJ. Impact of metformin on cardiovascular disease: a meta-analysis of randomised trials among people with type 2 diabetes. Diabetologia 2017; 60: 1620-1629.

[19] Solymár M, Ivic I, Pótó L, et al. Metformin induces significant reduction of body weight, total cholesterol and LDL levels in the elderly - a meta-analysis. PLoS ONE 2018; 13: e0207947.

[20] Bundesärztekammer (BÄK), Kassenärztliche Bundesvereinigung (KBV), Arbeitsgemeinschaft der Wissenschaftlichen Medizinischen Fachgesellschaften (AWMF). Nationale VersorgungsLeitlinie Therapie des Typ-2-Diabetes - Langfassung, 1. Auflage. Version 3. 2013, zuletzt geändert: April 2014. Available from: http://www.versorgungsleitlinien.de/themen/diabetes2/ dm2_therapie [accessed: September 3 2019]. DOI: 10.6101/ AZQ/000203.

[21] Levey AS, Stevens LA, Schmid CH, et al. A new equation to estimate glomerular filtration rate. Ann Intern Med. 2009; 150: 604-612.

[22] Stevens RJ, Kothari V, Adler AI, et al. The UKPDS risk engine: a model for the risk of coronary heart disease in Type II diabetes (UKPDS 56). Clin Sci (Lond). 2001; 101: 671-679.

[23] Preiss D, Lloyd SM, Ford I, et al. Metformin for non-diabetic patients with coronary heart disease (the CAMERA study): a randomised controlled trial. Lancet Diabetes Endocrinol. 2014; 2: $116-124$

[24] Davies MJ, D'Alessio DA, Fradkin J, et al. Management of hyperglycaemia in type 2 diabetes, 2018. A consensus report by the American Diabetes Association (ADA) and the European Association for the Study of Diabetes (EASD). Diabetologia 2018; 61: 2461-2498

[25] Jermendy G, Kiss Z, Rokszin G, et al. Trends in antidiabetic treatment prescribed for patients with type 2 diabetes in Hungary between 2001 and 2014 - results from the database analysis of the National Health Insurance Fund. [A 2-es típusú diabetes antihyperglykaemiás kezelésének alakulása Magyarországon 2001-2014 között - az Országos Egészségbiztosítási Pénztár adatbázis-elemzésének eredményei.] Orv Hetil. 2017; 158: 770-778. [Hungarian]

[26] Rena G, Hardie DG, Pearson ER. The mechanisms of action of metformin. Diabetologia 2017; 60: 1577-1585.

[27] Pernicova I, Korbonits M. Metformin - mode of action and clinical implications for diabetes and cancer. Nat Rev Endocrinol. 2014; 10: 143-156.

[28] Winkler G. Metformin - new data for an "old", but efficient, safe and reliable antidiabetic drug. [Metformin - újabb adatok egy megbízható és hatékony „régi” vércukorcsökkentő készítményről.] Orv Hetil. 2016; 157: 882-891. [Hungarian]

[29] Stevanovic D, Janjetovic K, Misirkic M, et al. Intracerebroventricular administration of metformin inhibits ghrelin-induced hypothalamic AMP-kinase signalling and food intake. Neuroendocrinology 2012; 96: 24-31.

[30] Maida A, Lamont BJ, Cao X, et al. Metformin regulates the incretin receptor axis via a pathway dependent on peroxisome proliferator-activated receptor-alpha in mice. Diabetologia 2011; 54: 339-349

[31] Woo SL, Xu H, Li H, et al. Metformin ameliorates hepatic steatosis and inflammation without altering adipose phenotype in diet-induced obesity. PLoS ONE 2014; 9: e91111.

[32] Malin SK, Kashyap SR. Effects of metformin on weight loss: potential mechanisms. Curr Opin Endocrinol Diabetes Obes. 2014; 21 : 323-329.

[33] Demetz E, Schroll A, Auer K, et al. The arachidonic acid metabolome serves as a conserved regulator of cholesterol metabolism. Cell Metabolism 2014; 20: 787-798.

[34] Bridgeman SC, Ellison GC, Melton PE, et al. Epigenetic effects of metformin: from molecular mechanisms to clinical implications. Diabetes Obes Metab. 2018; 20: 1553-1562.

[35] Elbere I, Silamikelis I, Ustinova M, et al. Significantly altered peripheral blood cell DNA methylation profile as a result of immediate effect of metformin use in healthy individuals. Clin Epigenetics 2018; 10: 156.

[36] Hong J, Zhang Y, Lai S, et al. Effects of metformin versus glipizide on cardiovascular outcomes in patients with type 2 diabetes and coronary artery disease. Diabetes Care 2013; 36: 13041311.

[37] Norwood DK, Chilipko AA, Amin SM, et al. Evaluating the potential benefits of metformin in patients with cardiovascular disease and heart failure. Consult Pharm. 2013; 28: 579-583.

[38] Giugliano D, De Rosa N, Di Maro G, et al. Metformin improves glucose, lipid metabolism, and reduces blood pressure in hypertensive, obese women. Diabetes Care 1993; 16: 1387-1390.

[39] Hermann LS, Scherstén B, Bitzén PO, et al. Therapeutic comparison of metformin and sulfonylurea, alone and in various combinations. A double-blind controlled study. Diabetes Care 1994; 17: 1100-1109.

[40] Matsumoto K, Sera Y, Abe Y, et al. Metformin attenuates progression of carotid arterial wall thickness in patients with type 2 diabetes. Diabetes Res Clin Pract. 2004; 64: 225-228.

[41] Chakrabarti R, Hocking ED, Fearnley GR. Fibrinolytic effect of metformin in coronary-artery disease. Lancet 1965 ; 286 : 256259.

[42] Fanghanel G, Silva U, Sanchez-Reyes L, et al. Effects of metformin on fibrinogen levels in obese patients with type 2 diabetes. Rev Invest Clin. 1998; 50: 389-394.

[43] Mather KJ, Verma S, Anderson TJ. Improved endothelial function with metformin in type 2 diabetes mellitus. J Am Coll Cardiol. 2001; 37: 1344-1350.

[44] Giacco F, Brownlee M. Oxidative stress and diabetic complications. Circ Res. 2010; 107: 1058-1070.

[45] Bierhaus A, Nawroth PP. Multiple levels of regulation determine the role of the receptor for AGE (RAGE) as common soil in inflammation, immune responses and diabetes mellitus and its complications. Diabetologia 2009; 52: 2251-2263. 
[46] Groener JB, Oikonomou D, Cheko R, et al. Methylglyoxal and advanced glycation end products in patients with diabetes - what we know so far and the missing links. Exp Clin Endocrinol Diabetes 2017 Apr 13. doi: 10.1055/s-0043-106443. [Epub ahead of print]

[47] Maqbool M, Cooper ME, Jandeleit-Dahm KA. Cardiovascular disease and diabetic kidney disease. Semin Nephrol. 2018; 38: 217-232.

[48] Beisswenger PJ, Howell SK, Touchette AD, et al. Metformin reduces systemic methylglyoxal levels in type 2 diabetes. Diabetes 1999; 48: 198-202.
[49] Kender Z, Fleming T, Kopf S, et al. Effect of metformin on methylglyoxal metabolism in patients with type 2 diabetes. Exp Clin Endocrinol Diabetes 2014; 122: 316-319.

[50] Peters AS, Wortmann M, Fleming TH, et al. Effect of metformin treatment in patients with type 2 diabetes with respect to glyoxalase 1 activity in atherosclerotic lesions. Vasa 2019; 48: 186-192.

(Kender Zoltán dr., Heidelberg, Im Neuenheimer Feld 410, 69120 Germany e-mail: zoltan.kender@med.uni-heidelberg.de)

\section{ERRÁTUM}

Sajnálattal tudatjuk, hogy az Orvosi Hetilap ez évi 160. kötetének 31. füzetében, a 1207-1215. oldalakon megjelent Jermendy György dr. „Az antihyperglykaemiás terápia deeszkalációja 2-es típusú diabetesben - amikor a kevesebb több” címú közleményének 1214. oldalán a 2. ábrában a korrektúraforduló után, a nyomdai munka során, tehát nem a szerző hibájából a papírváltozatban kimaradtak a nyilak. A nyilakat tartalmazó hibátlan ábrát ezennel közöljük.

\begin{tabular}{|c|c|c|c|c|c|}
\hline \multirow[t]{3}{*}{ Stádiumok } & \multirow{3}{*}{$\frac{\text { Normoglykaemia }}{\text { Normális glükózreguláció }}$} & \multicolumn{4}{|c|}{ Hyperglykaemia } \\
\hline & & \multirow{2}{*}{$\begin{array}{l}\text { Csökkent glükóztolerancia } \\
\text { vagy emelkedett éhomi } \\
\text { vércukor (prediabetes) }\end{array}$} & \multicolumn{3}{|c|}{ Diabetes mellitus } \\
\hline & & & $\begin{array}{c}\text { Inzulint } \\
\text { nem igénylő }\end{array}$ & $\begin{array}{l}\text { Inzulin szükséges } \\
\text { az anyagcsere- } \\
\text { kontrollhoz }\end{array}$ & $\begin{array}{c}\text { Inzulin szükséges } \\
\text { a túléléshez }\end{array}$ \\
\hline \multirow{3}{*}{\multicolumn{6}{|c|}{$\begin{array}{l}\text { 1-es típus* } \\
\text { 2-es típus } \\
\text { Egyéb speciális ípusok** }\end{array}$}} \\
\hline & & & & & \\
\hline & & & & & \\
\hline Gesztációs diabetes** & 4 & & & $\longrightarrow$ & \\
\hline
\end{tabular}

2. ábra $\quad$ A glükózanyagcsere rendellenességei - típusok és stádiumok [46]. (Forrás: American Diabetes Association: Diabetes Care 2011; 34(Suppl 1): S62S69)

*Előfordul, hogy ketoacidosis tünetei után rövid időn belül normoglykaemia detektálható, s antidiabetikus gyógyszeres kezelés nem szükséges („honeymoon" periódus)

**Ritkán előfordul, hogy idetartozó betegek esetében a túléléshez inzulin adása válik szükségessé (pl. Vacor-mérgezés, l-es típusú diabetes kialakulása terhesség alatt).

A cikk a Creative Commons Attribution 4.0 International License (https://creativecommons.org/licenses/by/4.0/) feltételei szerint publikált Open Access közlemény, melynek szellemében a cikk bármilyen médiumban szabadon felhasználható, megosztható és újraközölhető, feltéve, hogy az eredeti szerző és a közlés helye, illetve a CC License linkje és az esetlegesen végrehajtott módositások feltüntetésre kerülnek. (SID_1) 